\title{
A Summary of Indian State-owned Enterprises Operation Against the Background of Comprehensive Reform
}

\author{
Jing Tu \\ School of Economics \\ Sichuan University \\ Chengdu, China
}

\begin{abstract}
The development of modern state-owned enterprises in India has gone through 60 years, and the stateowned institutional mechanism has also slowly transitioned from the context of the "socialist economy of the Nehru era" to the context of comprehensive reform in the Rao era. Due to the special environment existing in the transformation of Indian state-owned enterprises, the operating system of modern and contemporary state-owned enterprises in India is different from other countries. This paper aims to make the readers realize that the focus of state-owned enterprise reform is the institutional mechanism by elaborating the characteristics and problems that have emerged since the reform of the state-owned enterprise in India in 1991. Therefore, the paper will focus on the three mechanism of equity, technological innovation and talents, and market competition that affect the performance of Indian stateowned enterprises to make relevant description. Through the review of this paper, the overall direction of India's future stateowned enterprise reform is obtained. At the same time, through the analysis of this paper, it can also provide a realistic reference for the relevant state-owned enterprises in China, a developing country also facing the reform problems of state-owned enterprises.
\end{abstract}

Keywords-reform of state-owned enterprises in India; institutional mechanism; privatization

\section{INTRODUCTION}

Since India' s independence, especially during the Nehru administration, in order to build a "socialist economy" , a mixed economic system dominated by state-owned enterprises has been implemented. The operation of state-owned enterprises, in the early days of industrialization in India, in the era of leading thinking of self-reliance, has played a significant role in promoting India' s military industry, heavy chemical industry, aerospace, energy, railway and other industries that have a bearing on the national economy. At the same time, it has also driven the development of a considerable number of surrounding industries. Since the independence of India, the state owned enterprises once the forward position for India(i.e., the National Congress party) to implement the high-tech development strategy, foster scientific and technological talents and realize the leap of science and technology .However, similar to the situation in the former
Soviet Union, because the Nehru administration paid too much attention to the construction of industry, especially heavy industry and ignored the development of agriculture, India national economy paid a painful price, especially the difficulties faced by India's grain production in the early 1960s.After Nehru's death, his daughter, Indira Gandhi, started a "green revolution", beginning to attach importance to the development of agriculture, and started the first round of the reform of India's state-owned enterprises since independence. In 1980s, when Indira Gandhi came to power secondly, he also carried out the second rounds of reform of state-owned enterprises in India, together with the subsequent La Gandhi period. The previous reform was dominated by the "ten point economic programme", and the latter was dominated by rectification and liberalization, and the reform measures in some areas in the period of the La Gandhi period were more radical. However, these reforms failed in general and did not change the long-term management difficulties and stagnation of state-owned enterprises. When Rao came to power in 1991, the state-owned enterprises began to reform in an all-round way.

This paper makes a brief overview of the main operational institutional mechanism of the present and contemporary stateowned enterprises in India since the implementation of the comprehensive reform of the privatization of state-owned enterprises $^{1}$ in 1991. It mainly involves three representative aspects, the first one is the system of property rights and equity, the second one is the innovation mechanism of science and technology and the mechanism of talent, and the third is the market competition mechanism and make a comparison of the contribution of national economy before and after the reform of state-owned enterprises in India. This paper can provide a certain basis and reference for the article focusing on more indepth study of the operational efficiency and internal governance mechanism of the present and contemporary stateowned enterprises to improve the institutional mechanism of state-owned enterprises and improve the competitiveness of

India law stipulates that enterprises with $51 \%$ components as public shares belong to public owned enterprises, so the definition of privatization is to make the state-owned components in original state-owned enterprises fall below $51 \%$ in China. 
state-owned enterprises in India, and even the similar BRICs countries.

\section{AN OVERVIEW OF THE STATUS QUO AND PROBLEMS OF INDIAN STATE-OWNED ENTERPRISE REFORM}

\section{A. The Characteristics of the Reform of the State-owned Enterprises in India Since 1991}

At the beginning of Rao's coming to power in 1991, India experienced a serious foreign exchange reserve crisis. The foreign exchange reserves were left with 1 billion US dollars. It was only used for two weeks. The ruling Congress Party urgently used reserve gold to exchange foreign exchange from the IMF to survive the crisis and began a relatively systematic road to state-owned enterprise reform. ${ }^{2}$ Its sign is that privatization has begun to advance in substance, support in key areas has been strengthened, and restrictions on foreign investment have been relaxed. The economic policy implemented by the Rao government basically abandoned Nehru's mixed ownership model and promoted privatization in the following six aspects: 1) The model of supplementing the state-owned enterprises by the private enterprises in the past has been turned into the model of supplementing the private enterprises by the state-owned enterprises; 2) substantial tax reduction has been carried out for private enterprises; 3) financial institutions support has been biased towards private enterprises; 4) private companies have been allowed to be engaged in trading; 5) the further liberalization of foreign capital has been performed through the form of solidification, which would effectively eliminate the embarrassing situation of foreign capital withdrawing from India in the late 1970s. Later, it has been turned out that this is indeed the successful case; 6) privatizing a large number of loss-making state-owned enterprises. For example, in the electrical industry, irrigation industry, road transport industry, loss-making state-owned enterprises are more than half and the degree of privatization of these industries is also the highest in the reform. ${ }^{3}$

It can be said that the privatization reform of state-owned enterprises promoted by the Rao government since 1991 has been unprecedented in the history of India, and it is also the most radical. It has the same effect as the "shock therapy" carried out in Russia and Eastern Europe at the same time. The wave of privatization that began in the 1990s was the third wave of privatization in the world since the end of World War $\mathrm{II}^{4}$. India also had privatization before the 1990s. For example, during Rajiv Gandhi's reign, he tried privatization for Uttar Pradesh Cement Company, but such cases accounted for only a small percentage. After La Gandhi was killed, Rao took office and began a real large-scale privatization process.

\footnotetext{
2 Yu Hailian. Development and Reform of Indian State-owned Enterprises.

Wu Yongnian. India in Change - A New Perspective on Indian

Countries in the 21st Century[M]. People's Publishing House, 2011.

The first two are the wave of privatization of state-owned enterprises led by the United Kingdom, and the wave of privatization of public enterprises led by the United States and the East Asian Tigers in the early and mid 1980s. The latter was mainly influenced by Reagan Economics.
}

However, there are also differences between the reform of state-owned enterprises in India and the general privatization reform of state-owned enterprises in Eastern Europe, which are mainly lie in that:1) The reform of state-owned enterprises in India is gradual. For example, in the reduction of state-owned shares, it is divided into two stages: the early 1990s and the mid-late 1990s. The early stage was mainly limited to a limited scope, with the aim of enhancing the overall competitiveness of state-owned enterprises; in the latter stage, the reduction of state-owned shares were divested to all non-strategic stateowned enterprises 5 , and some "sick enterprises" were shut down and transferred until completely eliminated. 2) In addition to measures such as privatization and closure of some poorly-profit state-owned enterprises, the state-owned enterprises with better profitability have adopted a "memorandum of understanding" and a classification management method. The "memorandum of understanding" is an incentive mechanism based on the conclusions of experts and other professionals in the industry for the expansion of corporate autonomy; the specific approach adopted by classification management is to divide enterprises into core and non-core categories, and the latter are divided into noncore I and non- Core II, which in turn determine the extent to which state-owned enterprises have operational and financial autonomy. ${ }^{6} 3$ ) The implementation of the "voluntary retirement plan" for state-owned enterprise staff has undergone two rounds of revisions. The newly revised plan was passed in 2000, confirming that the government and financial institutions jointly support to help retirees and ensure that the old and new alternately proceed smoothly in the state-owned enterprises. 4) For some strategic state-owned enterprises, the Indian government implements the professionalization of the board of directors, that is, the proportion of elites and professionals in the industry to which the board must have is more than one third. This measure actually strengthens the status of strategic state-owned enterprises in India's economic society.

\section{B. The Main Problems Reflected in the Reform of Indian State-owned Enterprises}

In India's large-scale reform of state-owned enterprises, which began in 1991, there have also been many problems, including:

1) The bureaucratic atmosphere is serious. After the reform, there are still many authorities in India's state-owned enterprises. The main institutions that manage Indian stateowned enterprises are the National Audit Office, the Federal Parliament (State Assembly), the Ministry of Finance, the National Planning Commission, and the Ministry of Labor. India's state-owned enterprises' main leadership of "airborne" is still widespread and cannot be generated internally. It is also mixed with some nepotism. ${ }^{7}$ This phenomenon makes it

\footnotetext{
5 Strategic state-owned enterprises are mainly railways, military industry and nuclear energy sectors, and other former state-owned enterprises are non strategic sectors.

6 Li Junjiang. He Xiaoyin. Indian State-owned Enterprise Reform and Its Performance[J]. Journal of Henan Mechanical and Electrical Engineering College, 2005.3.

Yu Hailian. Development and Reform of Indian State-owned Enterprises[J]. Contemporary Asia-Pacific Studies, 2001.11
} 
difficult to eradicate the situation in which the predecessors are staffed.

2) Some state-owned enterprises still have serious problems such as rebate and cut off material, which is mainly due to the fact that the internal supervision and scope of the state-owned enterprises in India after the reform are still small compared with the private enterprises. As a result of the above phenomenon, it has also caused the state-owned enterprises to delay the construction of some projects, sometimes even longer than 20 times longer, becoming a real "uncompleted project". 8

3) The price positioning is unreasonable. The price of Indian state-owned enterprises after the reform is still mainly determined by national policies. Although some prices of stateowned enterprise products have some adjustments according to the principle of marketization, they are still not subject to market constraints. India's state-owned enterprise products are also not transparent in their price setting process. These phenomena are particularly prominent in power, mining, petrochemical, transportation, military, etc., making the basic cost of India's bulk products high, thus restricting the development of other industries, especially the private economy.

4) The competitiveness of the former state-owned enterprises has deteriorated compared with the enterprises and departments that have been privatized. The data shows that since 1991, the average value-added of unprivatized stateowned enterprises is only $26.8 \%$, while the value-added of state-owned enterprises that have been privatized has reached $73.2 \%{ }^{9}$

5) State-owned enterprises have excessive investment but too little savings, and the investment result has been very poor. The data also shows that among the 52 large and mediumsized state-owned enterprises surveyed in 1994-1995, the investment of unprivatized state-owned enterprises accounted for $9.4 \%$ of the total assets, while the savings accounted for only $1.6 \%$ of the total assets; the investment value of privatized state-owned enterprises accounted for $14.21 \%$ of total assets, while savings accounted for $20.2 \%$ of total assets. $^{10}$

The reasons of these problems are attributed to the institutional mechanism. It is generally believed that the institutional mechanisms in the reform of state-owned enterprises are most prominent in the process of equity allocation (or ownership), technological innovation and market competition. These are all decisive factors affecting the reform results of state-owned enterprises. So in the next section we will describe the above mechanism.

\section{A BRIEF INTRODUCTION TO THE INSTITUTIONAL MECHANISM OF THE OPERATION OF INDIAN STATE-OWNED ENTERPRISES IN THE CONTEXT OF COMPREHENSIVE REFORM}

Traditionally, Indian state-owned enterprises are generally divided into four categories, namely, industrial and commercial state-owned enterprises, manufacturing stateowned enterprises, commerce and trade state-owned enterprises, and state-controlled enterprises. Since the reform of the comprehensive state-owned enterprises in India in 1991, the above four types of enterprises have changed to varying degrees of institutional mechanisms, but the state-owned enterprises in manufacturing have the most profound changes and the highest degree of privatization. At the same time, the state-owned manufacturing enterprises' technological innovation system and market competition system have also been optimized. It must be mentioned that despite this, after more than 20 years of reform, the operating performance and overall competitiveness of Indian state-owned manufacturing enterprises are still relatively low.

\section{A. Separate Narration of Shareholding System Reform}

One of the relatively important parts of India's reform since 1991 is the transfer of state-owned shares. The objects of the transfer include the original enterprise employees (generally those with good performance or outstanding performance, with great potential for growth) and private financial institutions (India began to privatize financial institutions in 1969, and private banks in India accounted for a considerable proportion before the reform of state-owned enterprises in $1991^{11}$ ) The term "equity" usually refers to ownership, different from property rights. The former emphasizes management rights, the latter emphasize on the right to cope. The transfer of state-owned enterprise equity is to transfer part of the operating rights in the case that property rights are belong to state, in order to ensure the profitability of this part of the transferred assets.

For example, in refineries, heavy-duty electrical, eyewear manufacturing, cable manufacturing, natural gas and some other industries, state-owned shares have a certain degree of transfer, and some industries are even high in transferring degree.

The following are the transferring of few state-owned shares of the above-mentioned industries in India from the start of the reforms in 1992 to 1994 :

\footnotetext{
Yang Wenwu. Economic Globalization and the Reform of Indian State-owned Enterprises[J]. South Asian Studies Quarterly, No. 4, 2001.p3.

$9 \quad$ Yang Wenwu. On the Privatization of Indian State-owned Enterprises [J]. South Asian Studies Quarterly, No. 1 ,1998.p7. 10 (India) Political and Economic Weekly[J], December 1996, page
}

\footnotetext{
11 Yang Wenwu. On the Privatization of Indian State-owned Enterprises [J]. South Asian Studies Quarterly, No. 1, 1998. p8.
} 
TABLE I.

OVERVIEW OF THE TRANSFERRING PROPORTION OF STATEOWNED SHARES IN SOME INDUSTRIES IN INDIA ${ }^{12}$

\begin{tabular}{|l|l|l|}
\hline Company name & 1992 & End of 1994 \\
\hline India Cochin Refinery & $38.40 \%$ & $44.96 \%$ \\
\hline Indian Oil and Gas Commission & $0.00 \%$ & $2.00 \%$ \\
\hline Indian Electronics Co., Ltd & $0.00 \%$ & $24.04 \%$ \\
\hline Indian National Textile Company & $0.00 \%$ & $2.35 \%$ \\
\hline $\begin{array}{l}\text { India heavy-duty Electric Co., } \\
\text { Ltd. }\end{array}$ & $0.00 \%$ & $31.54 \%$ \\
\hline $\begin{array}{l}\text { Indian State-owned Madras } \\
\text { Refinery }\end{array}$ & $15.38 \%$ & $48.20 \%$ \\
\hline $\begin{array}{l}\text { Indian State-owned Glasses Co., } \\
\text { Ltd. }\end{array}$ & $0.00 \%$ & $30.38 \%$ \\
\hline Hindustan Cable Co., Ltd & $0.00 \%$ & $2.63 \%$ \\
\hline
\end{tabular}

From "Table I", we can see that after the initial reforms, the selling proportion of Indian state-owned shares in the oil and gas industry is generally low, only $2.0 \%$, and still about $98 \%$ are in the hands of the public sector. This is mainly because oil and natural gas is an absolute strategic resource in India, 1 country lacking such resources, so it needs a state monopoly. In addition, few enterprises in India are willing to invest huge sums of money to buy such enterprises. However, we find that the sales rate of the state-owned Madras refinery in India is as high as $48.20 \%$. In the two years, the state-owned equity change from $15.38 \%$ to $48.20 \%$, which is diluted by $32.82 \%$. Why is this? This is mainly because the refining industry is different from the oil exploration industry and it has a higher degree of marketization. Therefore, the higher degree of privatization will help the profitability of such industries. In comparison, there are also high levels of privatization in India, such as electronic state-owned enterprises, state-owned glasses manufacturing companies, and heavy-duty electric state-owned enterprises. But the degree of privatization of cable companies is very low. The conditions are jointly determined by the strategic nature of the companies themselves, the difficulty of pricing, and the pressure of the government's financial support for the industry.

\section{B. Separate Narration on the Reform of the Scientific and Technological Innovation System and the Talent Mechanism}

The optimization of scientific and technological innovation mechanism is an issue that should not be avoided in the reform of state-owned enterprises. Since independence, India's technological innovation has been mainly completed by stateowned enterprises. The "Scientific Policy Resolutions" established in 1958 emphasized the use of national power to promote technological innovation. Large state-owned enterprises and enterprise organizations should become the vanguard of India's technological modernization. The technological innovation of state-owned enterprises is promoted along with the introduction of policies and the national scientific and technological institutions. For example, the Atomic Energy Commission established in 1958 has enhanced the innovation capability of large state-owned enterprises related to nuclear energy; the Space Science

12 Data Sources: Indian government Annual Economic Survey 19951996_quoted from Yang Wenwu. On the Privatization of Indian Stateowned Enterprises[J]. South Asian Studies Quarterly, No. 1 of 1998.p12.
Research Headquarters, established in 1962, with its offices in Bangalore, has enabled a large number of state-owned enterprises to provide technical support and equipment for space science. With the support of national science and technology policies, Bangalore has become the largest electronics industry park in India, known as Silicon Valley in India. ${ }^{13}$ However, before the reform, the state-owned enterprises' scientific and technological innovation mechanism was limited to a small number of state-owned enterprises. Since 1991, the Indian government has adopted incentive measures for scientific and technological innovation for a number of key state-owned enterprises, mainly including: 1) actively encouraging large and medium-sized state-owned enterprises to enter the unknown and high-end technology fields through the establishment of various institutions and policy support; 2) actively encouraging Indian state-owned enterprises to cooperate with foreign counterparts in the hightech field; 3) facilitating the financing of scientific and technological innovation of state-owned enterprises through various channels.

Since the comprehensive reform, for the high efficiency of state-owned enterprises, the Indian government has taken some positive measures in the talent training and management mechanisms of some state-owned enterprises, including: 1) Jointly cultivating scientific and technological innovation talents with large foreign high-tech enterprises. For example, in 1999, India's state-owned information technology company and Microsoft Corporation of the United States jointly established "MICROSOFT-NET Company". All of the company's Indian information technology and software talents will be engaged in design work on Microsoft's platform, which provides convenience for India to obtain the latest network technology; ${ }^{14}$ 2) retaining talents with high salaries and giving them considerable development space. For example, Larsen \& Toubro Ltd., an Indian state-owned construction company has set a minimum annual salary of 100,000 US dollars per year to recruit returnees from $2004 .^{15}$

\section{The Separate Narration on the Reform of Market Competition Mechanism}

According to Liu Yijun's (2000) definition of the market competition mechanism of enterprises, the market competition mechanism is not only an "incentive" mechanism but also a "elimination" mechanism for an enterprise, and the survival of the fittest. In essence, it is a "modern scientific management system that wholeheartedly depends on the working class." 16 Yang Wenwu (2001) believes that the pressure of comprehensive competition of Indian state-owned enterprises since the comprehensive reform actually comes from two aspects. The one is the fast-growing private enterprises in India,

13 Wen Fude. India's High-tech Development Strategy Research[M]. Sichuan Publication Group, 2011.4, p275.

14 Lin Hanchuan. Organizational Form and Leadership System of Indian State-owned Enterprises [J]. Foreign Economics \& Management, 1994(8): 19

15 Wen Fude. India's High-tech Development Strategy Research [M]. Sichuan Publication Group 2011.4, p277.

16 Liu Yijun. Thoughts on the Competition Mechanism of Chinese Enterprises [J]. Local Government Management, 2000.7. p31-32. 
and the other the pressure brought by the foreign-invested enterprises in India arising from the further development of economic globalization since the $1990 \mathrm{~s} .{ }^{17}$ To this end, Indian state-owned enterprises, which are prominently represented in the food, energy, railway and transportation industries, have adopted and implemented the following main measures:

1) Decentralization of operational autonomy. For energy companies, in order to strengthen their competition in the global energy market, the Indian government has formed a group of multinational energy-rich state-owned enterprises, adopting a professional approach to the board of directors. The state-owned enterprise capital management is mainly completed by the board of directors with a high degree of autonomy.

2) The plan for the reduction of assets of the state-owned enterprises. From the following figure, it can be seen that the actual amount of the reduction of state assets reflected by the government budget has increased year by year since the comprehensive reform of India's state-owned enterprises.

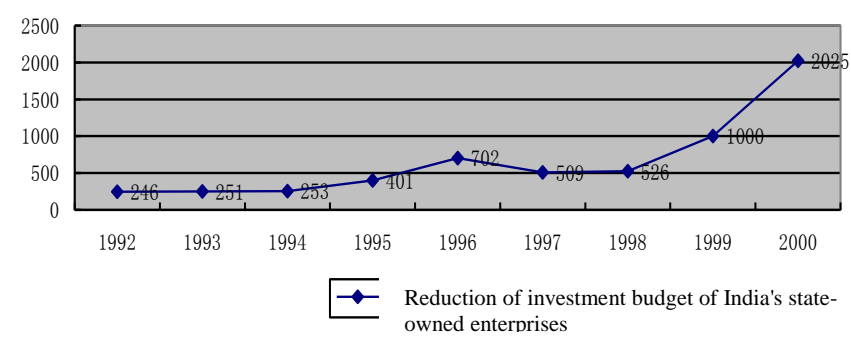

Fig. 1. The state of assets reduction of state-owned enterprises in India from 1992 to 2000 (Unit: 100 million rupee) ${ }^{18}$

It can be seen from "Fig. 1" in 1992, the state-owned enterprise assets reduction budget was only 24.6 billion rupees, and in 1996 it soared to 70.2 billion rupees. In 1997, it declined. The main reason was the impact of the Southeast Asian financial crisis. India's privatization and foreign investment entering have been tightened. Therefore, the reduction of Indian state-owned enterprise assets remained stable from 1997 to 1998 , at a low point. By the year 2000, India's state-owned assets reduction budget in the new century had seen a new round of more powerful growth, eventually rushing to a high of 202.5 billion rupees.

3) Close "sick state-owned enterprises." For a long time, sick state-owned enterprises have taken away a lot of resources from the state's financial and financial institutions, but they have not recovered from life and have not been able to survive for a long time until they have stepped into the door of death. Since the comprehensive reforms in India in 1991, in order to improve the overall competitiveness of state-owned enterprises, these "sick enterprises" and "zombie enterprises" have been drastically rectified and shut down. According to the information provided by India's Economic Survey of 1999-

\footnotetext{
17 Yang Wenwu. On the Privatization of Indian State-owned Enterprises[J]. South Asian Studies Quarterly, No. 1 of 1998. p3-5.

18 Source of information: Organized according to some data provided by the Government Budget Report of India (2001)
}

2000, 29 sick enterprises and zombie enterprises of the 240 state-owned enterprises surveyed were completely shut down, and 7 of the above-mentioned types of enterprises were notified to close for a limited period of time. Later, in the different time, the companies gradually withdrew from the registration, and six of the above-mentioned types of enterprises were ordered to rectify and removed the hat of "sick enterprise".

It is worth mentioning that after a new round of market competition mechanism changes, whether the comprehensive competitiveness of state-owned enterprises in many fields in India is improved is an object of concern. If the weighted average number $\mathrm{O}$ of the four indicators of corporate financial efficiency, corporate asset operating status, corporate solvency and enterprise development potential are used to make a comprehensive evaluation ${ }^{19}$. Here, Li Qingdong (2004) created a method for evaluating the comprehensive competitiveness index system and valuation of enterprises: $O$ represents the collection of the evaluation index system for the competitiveness of Indian state-owned enterprises, $\mathrm{O}=\{\mathrm{A}, \mathrm{B}, \mathrm{C}, \mathrm{D}\}$, the $\mathrm{ABCD}$ here represents the financial benefits of the enterprise, the operation status of the enterprise assets, the solvency of the enterprise and the development potential of the enterprise respectively, and $A=\{A 1$, $\mathrm{A} 2, \ldots\}, \mathrm{B}=\{\mathrm{B} 1, \mathrm{~B} 2, \ldots\}, \mathrm{C}=\{\mathrm{C} 1, \mathrm{C} 2, \ldots\}, \mathrm{D}=\{\mathrm{D} 1$, $\mathrm{D} 2, \ldots\}$. Here, A1, A2, B1, ..., etc. respectively represent factors affecting the above four sub-indicators. For the actual score of each of the above sub-indicators, the Delphi method can be used and the results are all scored by the experts "back to back".

After determining the weights and scores of each subindicator for an enterprise, the comment and weight coefficient matrix $\mathrm{F}$ can be got and then the target layer comprehensive evaluation set $\mathrm{B}$ shall be calculated, and finally the comprehensive evaluation value $\mathrm{X}=\mathrm{BF}$, which is a specific value got by the multiplication of the two matrices. It is possible to select a number of companies with typical characteristics in India, and divide the time from 1991 to 2005 into small segments ${ }^{20}$. The comprehensive evaluation values for each time period should be all calculated and compared.

\section{CONCLUSION}

From the above description of the institutional mechanisms such as equity, technological innovation and talents, and market competition since the reform of Indian state-owned enterprises, it can be found that:

\section{Many domestic literatures generally introduce the concept of} market share level when analyzing the market competitiveness of enterprises. This paper does not use the market share as an indicator. The author believes that for Indian state-owned enterprises, the market share has changed little, mainly because the development of private enterprises has completely occupied many market space for state-owned enterprises. Therefore, "market share" does not accurately reflect the changes in the market competitiveness of India state-owned enterprises since comprehensive reform.

20 For example, it can be divided into four sections from 1991 to 1994 1995 to 1998,1999 to 2001, and 2002 to 2005 to make analysis. The value of each sub-indicator can refer to the enterprise real data at the end of each time period. 
- Affected by multiple factors such as strategic monopoly nature, fiscal pressure and pricing dilemma, the equity allocation of Indian state-owned enterprises is uneven among industries. Relatively speaking, the proportion of equity transfer in manufacturing state-owned enterprises is relatively large, but it cannot completely reverse the long-term loss of such enterprises.

- In terms of state-owned enterprise innovation mechanism and talent mechanism, some state-owned enterprises in India have vigorously introduced overseas talents through joint ventures with foreign excellent enterprises, implemented generous treatment of talents and provided a broader development space. In addition, they competed with private enterprises for high-end talents.

- In terms of market competition mechanism, the stateowned enterprises in India after 1991 adopted the gradual decentralization of operational autonomy, the reduction of state-owned assets and the closure of "sick enterprises" to enhance the overall competitiveness of state-owned enterprises and the measures have got significant results.

In view of this, the author proposes the overall direction of India's future state-owned enterprise reform. It can also provide a realistic reference for China, which is also a large developing country and also faces the "deep water zone" of state-owned enterprise reform:

- It is necessary to make great efforts to solve the problem of unclear property rights of state-owned enterprises. On the whole, in the early stage of the comprehensive reform of the state-owned enterprises in India, the degree of active transfer of equity and the decentralization of management rights are much larger than those of China. The nature of Indian state-owned enterprises and China used to copy the Soviet model, but the relationship between state-owned enterprises and government authorities in India is more flexible than China's, so the resistance encountered in the reform process is relatively small and the Information is also relatively more transparent.

- The pricing dilemma of SOE products must be resolved through financial means. At this stage, many stateowned enterprises with price monopoly in India still exist, which not only transfers the excess price to consumers, but also increases the burden on consumers. At the same time, it also creates space for government rent-seeking, and further curbs the development of private enterprises. The most typical is the telecommunications industry. It should be said that all kinds of SOEs will encounter such problems in the process of transformation, but India should start from the institutional mechanism to vigorously break through the bottleneck of state-owned enterprise reform one after another.

\section{REFERENCES}

[1] Lin Hanchuan. Organizational Form and Leadership System of Indian State-owned Enterprises[J]. Foreign Economics \& Management, 1994 (8): 14-16.

[2] Chen Minghua. The Problems Existing in Indian State-owned Enterprises and the Government's Countermeasures[J], Southeast Asian Studies, 1995(2):50-54.

[3] Zhao Ai. International Comparison of Operating Mechanisms of Stateowned Industrial Enterprises_-Analysis Report on France, Sweden, Italy, India and Brazil[J]. China Industrial Economy, 1992(11):67-75.

[4] Qiu Wei. The Road to State-owned Enterprises (India) [M]. Lanzhou University Press, 1999.

[5] Hua Biyun. The Hard Journey to Industrialization in India[J]. China Finance, 2006(9):64-66.

[6] Li Qingdong. Research on Evaluation Index System and Evaluation Method of Enterprise Competitiveness. Journal of Liaoning Shihua University, March 2004.P94.

[7] Gautam Ahuja, Sumit K. Majumdar.An Assessment of the Performance of Indian State-Owned Enterprises.Journal of Productivity Analysis, 1998, Vol.9 (2), pp.113-132

[8] Witold Kasperkiewicz, Wacława Starzyńska.Privatization of stateowned enterprises in Poland.International Advances in Economic Research, 1998, Vol.4 (1), pp.16-23

[9] A. Brandão, S. Castro.State-owned enterprises as indirect instruments of entry regulation.Journal of Economics, 2007, Vol.92 (3), pp.263-274

[10] Georges Enderle.Integrating the Ethical Dimension into the Analytical Framework for the Reform of State-Owned Enterprises in India's Socialist Market Economy: A Proposal.Journal of Business Ethics, 2001, Vol.30 (3), pp.261-276 